\begin{tabular}{c} 
Volume and Issues Obtainable at Center for Sustainability Research and Consultancy \\
Review of Politics and Public Policy in Emerging Economies \\
ISSN: 2708-3829 (E): 2708-356X \\
Volume 1: No. 1, June 2019 \\
¿SRᄃ \\
Journal homepage: www.publishing.globalcsrc.org/rope \\
\hline
\end{tabular}

\title{
Impact of Food Security Initiative on Sustainable Development in North Eastern Nigeria
}

\author{
${ }^{1}$ Sadeeq Garba Abubakar,${ }^{2}$ Yusuf Ova Mutalib, ${ }^{3}$ Muhammad Zia-Ul-Rahman Abubakar \\ ${ }^{1}$ Department of Business Administration and Management, Federal Polytechnic Bauchi, Nigeria; \\ sadeeqgarbatee@yahoo.com \\ 2 Department of Accountancy, Federal Polytechnic Bauchi, Nigeria; yomuta2002@yahoo.com \\ ${ }^{3}$ Bauchi State University, Gadau, Bauchi State Nigeria
}

\begin{tabular}{l}
\multicolumn{1}{c}{ ARTICLE DETAILS } \\
\hline History \\
Revised format: May 2019 \\
Available Online: June 2019 \\
Keywords \\
Food Security, Sustainability, \\
Availability, Adequacy and \\
Accessibility
\end{tabular}

JEL Classification:

L66, Q56

\begin{abstract}
Can human being survive without food? No doubt, food is life; hence, food has become an instrument of national power. It is within that imperatival need for food that this paper takes a cursory look at the issue in all its ramifications. The paper with a comprehensive review of food security initiative on sustainable development in North Eastern Nigeria (Sponsored by TETFUND). The results of this study may indicate positive and significant relationship between food security elements: Availability, Accessibility, Adequacy and sustainable to access to food with sustainable development. The study used primary source of data collection through the administration of questionnaires among various government agencies, corporate organizations, Non- governmental, buyers as well as sellers within the North Eastern Nigeria. Various statistics tools to include descriptive statistics, correlation analysis and regression analysis were used to analyze the data. The study recommends that stake holders, government authorities' should on promoting food security in order to achieve sustainable development. Donor agencies should channel resources in ensuring food security for sustainable development in developing countries especially in Nigerian and in particular the North Eastern part. Moreover, increased productivity should be directed towards keeping pace with the growing population and through improvement in technology, there would be sufficient food available in the country
\end{abstract}

\section{OPEN ACCESS}

(C) 2019 The authors, under a Creative Commons Attribution-

NonCommercial 4.0

Corresponding author's email address: sadeeqgarbatee@ yahoo.com

Recommended citation: Abubakar, S., Mutalib, Y. O. \& Abubakar, M. Z. U. R., (2019). Impact of Food Security Initiative on Sustainable Development in North Eastern Nigeria. Review of Politics and Public Policy in Emerging Economies, 1(1), 1-16

DOI: $10.26710 /$ rope.v1i1.1126

\section{Introduction}

Food is a need as well as a basic necessity of life. Its importance is seen in the fact that it is a basic means of sustenance and an adequate food intake, in terms of quantity and quality, is a key for healthy and productive life. Various foods serve as important "vehicles" for taking nutrients into the body and the body and bringing about human pleasure, hence, the need for food to be taken in the right quantity and quality. Food is essential to our survival, yet its production is undermining the environment upon which 
this survival is based. Food is a basic necessity of life and it is required for both human and economic development. Clean air and water, healthy soils, the presence of a diverse range of other living species and a climate to which we are adapted, collectively constitute our life support system.

Security of Food is the availability of food and one's access to it. A household is considered food secure when it occupants do not live in hunger or fear of starvation (FAO 2001). Food security exists when all people, at all times, have physical, social and economic access to sufficient, safe and nutritious food to meet their dietary needs and food preferences for an active and healthy life (Idachaba, 2006). Furthermore, food security is a constituent part of the broader concept of nutrition security. A household can be said to be nutritionally secure if it is able to ensure a healthy life for all its members at all times. Nutritional security thus requires that household members have access not only to food, but also to other requirements for a healthy life, such as health care, a hygienic environment and knowledge of personal hygiene. Food security is a necessary but insufficient condition for ensuring nutrition security.

Food securities serve as a prerequisite for the survival of mankind and his economic activities including food production. Food is different from other commodities because of its inevitability for survival and existence. In Nigeria, there is high level of food insecurity for the past four decades as a result of neglect in food production when oil has become the major export product and the because of the adoption of neoliberal economic policies such as devaluation of naira, trade liberalization and withdrawal of government from economic activities, ethnic and religious conflicts; disasters, such as flooding and drought have also contributed to food insecurity in Nigeria. Food is different from other commodities because everybody needs it for survival, and it is an indispensable factor in nation's quest for economic growth and development. Unfortunately, most of the food need in Nigeria is produced by peasant farmers who lack capital, skills, energy and other viable ingredients to produce on large quantity that will meet the requirement of the growing population. Thus food insecurity in Nigeria is a recurrent and double digit problem.

Sustainable food security is an access by all people at all times to enough food for an active healthy life at present plus the ability to provide enough for future generation. Issues on food security was brought to lime light in 1974 during the world food conference when it downed on the governments that nations all over the world needs to strategize on how best to improve agricultural production so as to match the per capita needs of the population. Ban Ki Moon, the UN Secretary- General at a World food summit in Rome in 2009, warned that six million children die of hunger every year; 17,000 die of starvation every day and by 2050 the world will need to feed two million more mouths. This has rekindled the idea of achieving sustainable food security in all countries of the world including Nigerian.

Sustainable development is said to be a widely used phrase and idea, which has many different meanings and therefore provokes different responses. In broad terms, the concept of sustainable development can be seen as an attempt to merge growing concerns about a range of environmental issues with socio-economic issues. Sustainable development has the potential to address fundamental challenges for humanity, now and into the future. However, to do this, it needs more clarity of meaning, concentrating on sustainable livelihoods and well-being rather than well-having and long term environmental sustainability, which requires a strong basis in terms of principles that may link the social and environmental factors to human equity.

The growing interest in the role of sustainable development in recent time has made, Government, Foreign/Donor agencies, Potential investors, Financial analysts and other stakeholders to rely more on food security to carry out fundamental analysis in predicting sustainable development than ever before. However, for food to be secured, it must availability, adequacy, accessibility and sustainability of access to all the citizens of the country. Since sustainability development is generated on availability, adequacy, accessibility and sustainability of access may be eroded by food insecurity. In light of this, scholars 
suggested that sustainability development is restricted on availability, adequacy, accessibility and sustainability of access to food

The issue of food security is more critical in developing economies than the developed economies due to the fact that, the developing countries are faced with more food security problem. In Nigeria, the perception and concern over a sustainable development in the presence of food security problem has generated debate among scholars on the availability, adequacy, accessibility and sustainability of access to food in aiding sustainability developmental is not yet over (Abdullahi, 2008: Dogondaji, 2013: Egbuna , 2001: Gurkan, 1995).

In the light of these conflicting results, this study investigates the impact of food security in predicting sustainable development in North Eastern Nigeria.

\section{Problem Statement}

The food 'problem' has become a global obsession. How much and what kind of food is produced, how and by whom; how it is moved, processed, packaged and sold and with what impacts; who gets what and how much to eat, and at the expense of whom and what the future might hold for all these variables; these questions are now the subject of measurement, analysis, critique and campaigning in research journals, policy documents, newspapers and television screens worldwide. (Godfray et al., 2010; Beddington et al., 2011; Foresight, 2011).

Any system where food demand is not sufficiently marched by supply is no doubt one with looming food crisis. Despite pretensions to the contrary, Nigeria is far from being completely food secured. At the global level, somewhere in the world, a child dies of hunger every five seconds, although the planet has more than enough food for all. The United Nations (UN) Secretary General, Ban Kimoon, laid out these sobering statistics as he kicked off a three day summit on world food security in Rome. "Today, more than one billion people are hungry", he told the assembly leaders. Six million children die of hunger every year, 17,000 every day. Dan Kimoon added that in 2050, the world will need to feed two million more mouths -9.1 billion in all (see, Nigerian Compass, November, 18, 2009:6).

Nigeria is blessed with abundant natural and human resources, but despite its significant natural resources, majority of the citizens are living below the poverty line. For instance according to WDI, (2015), an estimated $60 \%$ of Nigerians live on less than US\$1.25 per day. Nigeria was also ranked 91stout of a total of 104 counties on the 2015 Global Hunger Index and 153rdout of a total of 187countries on the 2012 UNDP Human Development Index. Malnutrition and hunger which is linked to poverty have been ravaging most developing countries and affecting their productive capacity. Classifying Nigeria as one of the poorest countries testifies to our failure to achieve our development policy as well as national food security. It once more awakened the government to the realities on ground, that is, the need to achieve the first sustainable development goal of no hunger before the year 2030.

For sustainable development of a nation is dependent on its factor endowment. This includes the nonhuman and human resources. The productive capacity of the human resources is however a function of how well fed they are. Food security problem, with regards to quality and quantity, is one of the characteristics of developing countries like Nigeria. The dimensions of food security make it clear that the concept of a food problem is a complex one with many dimensions. At one level the concern is with national food security, which is the ability of countries to produce or import sufficient food in all year to meet their requirement for both private and public distribution. At another level the concern is more with the problem of malnutrition. Therefore, for food security to be access by all people at all times, there must be sufficient food for a healthy and productive life i.e There must be availability, adequacy, accessibility and sustainability of access. 
The challenge is therefore to refashion the food system to deliver better nutritional outcomes at less environmental cost. But while this much is clear, the proposed solutions have been less coherently articulated and are certainly more contested. Stakeholders - across and within the food industry, civil society, policy makers and the research community have often strikingly different views on what should be done. It is argued here that broadly three perspectives are emerging in the debate on food system sustainability today. These in turn reflect different conceptualisations as to what is practically achievable given the variables of technological innovation, the functioning of the global economy and human motivations and behavior as well as different visions of what a sustainable food system actually looks like.

There are overwhelming evidences in literatures on food security in Nigeria ( Olayemi, 1996; World Bank, 1986; Adeyeye, 1992; Makinde, 2000; Oseni, 2001). However, most studies have focused on measuring food security using consumption expenditure and suggesting ways of solving the food problem. There is limited empirical evidence to show the impact food security initiative and sustainable development in North Eastern Nigeria

Given the critic on the food security for sustainable development in developing countries, it is imperative to provide an empirical evidence to unravel the claim that food security problem distorts sustainable development. Such evidence will allow government, foreign/ donor agencies financial analyst, economist and potential investors to know the extent to which they can rely on the elements of food security as veritable tools for sustainable development. Accordingly, this study investigate impact of food security initiative and sustainable development in North Eastern Nigeria

\section{Objectives of the study}

The main objective of this study was to critically investigate the impact of food security initiative on sustainable development in North Eastern Nigeria

The specific objectives based on the identified problems are :

- To determine the impact of Food Availability on Sustainable Development in North Eastern Nigeria.

- To ascertain the impact of Food Adequacy on Sustainable Development in North Eastern Nigeria.

- To examine the impact of Food Accessibility on Sustainable Development in North Eastern Nigeria.

- To evaluate the extent to Food Security initiative has impact on Sustainable Development in North Eastern Nigeria.

\section{Literature Review}

\subsection{Conceptualization}

\subsubsection{The Concept of Food Security}

According to Siamwalla and Valdes (1984), food security is the ability of countries, regions or households to meet target levels of food consumption on a yearly basis. Food security is a state of affairs where all people at all times have access to safe and nutritious food to maintain a healthy and active life (Gurkan, 1995). Similarly, it connotes physical and economic access to adequate food for all household members, without undue risk of losing the access.

Food security is defined as access by all people, at all times to sufficient food for an active and healthy life and includes at a minimum the ready availability of nutritionally adequate and safe foods, and an assured ability to acquire acceptable foods in socially acceptable ways (FAO, 1997; Sarah, 2003). Access to adequate food is a necessary but not a sufficient condition for a healthy life. A number of other factors, such as the health and sanitation environment and household or public capacity to care for vulnerable members of the society, also come into play (von Braun et al, 1992). 
Hoddinot cited in Seid (2007) noted that there are close to 200 definitions and 450 indicators of food security. A fundamental element in this category is the household's asset base. A household with several assets can more effectively maintain its consumption level by disposing of some of these assets. Its ability to do so increases according to the proportion of assets held in liquid form. Thus, the value and liquidity of assets are important determinants of a household's ability to cope with shocks to acquirement.

\subsubsection{Sustainable Food Security}

Sustainable food security has been defined in various ways by different scholars. According to WHO (1995) and FAO, et al. (2013) food security is access to the food needed by all people to enable them live a healthy life at all times. A country is said to be food secured when there is access to food of acceptable quantity and quality consistent with decent existence at all times for the majority of the population (Reutlinger, 1985; Idachaba, 2004). This means that food must be available to the people so as to meet the basic nutritional standard needed by the body. But it should be noted that availability of food does not mean accessibility to food. Availability depends on production, consumer prices, information flows and the market dynamics.

World Bank (1986) defined sustainable food security as an access to enough food for an active, healthy life at present as well as ability to provide enough in the future. Abudullahi (2008) defined sustainable food security as when people have physical and economic access to sufficient food to meet their dietary needs for a productive healthy life at present as well as in the future. This definition outlines some indices for measuring the extent or degree of food security to be achieved by any country and the indices are adequate national food supply, nutritional content, accessibility, affordability and environmental protection.

\subsubsection{Sustainable Development}

The widespread rise of interest in, and support for, the concept of sustainable development is potentially an important shift in understanding relationships of humanity with nature and between people. It is in contrast to the dominant outlook of the last couple of hundred years, especially in the "North" , that has been based on the view of the separation of the environment from socio-economic issues.

\subsubsection{Food Availability}

Availability of food plays a conspicuous role in food security. Having enough food in a nation is necessary but not adequate to ensure that people have satisfactory access to food. Over the years, population has increased faster than the supply of food thus resulting in food unavailability per person.

\subsubsection{Food Accessibility}

The ability to have access to food depends on two major conditions: - Economic access and physical access. Economic access depends on one's income, the price of food and the purchasing power of the people. Physical access depends on the availability and quality of infrastructure needed for the production and distribution of food. Lack of economic access to food is as a result of the increase in the rate of poverty.

\subsubsection{Food Utilization}

Food utilization is measured by two outcomes indicators which reflect the impact of inadequate food intake and utilization. The first outcome is measured by under-five years of age nutrition level while second measurement is quality of food, health and hygiene. According to FAO measuring the nutritional status of under-five years of age is an effective approximation for the entire population. The indicators for the measurement of under-five years of age are wasting (too thin for height); underweight (too thin for age) and stunting (too short for age). 


\subsubsection{Stability}

Stability has to do with exposure to short-term risks which have a way of endangering long-term progress. Key indicators for exposure to risk include climate shocks such as droughts, erosion and volatility in the prices of inputs for food production. The world price shocks leads to domestic price instability which is a threat to domestic food producers as they stand the chance of losing invested capital. Nigerian farmers are mainly smallholders farming mainly for subsistence, this makes it difficult for them to cope with changes in the prices of inputs, and it also lowers their ability to adopt new technologies thereby resulting in reduced overall production. Changing weather patterns as a result of climate change have played a part in reducing food supply, for instance flood in the southern parts of the country and drought in the northern parts leads to substantial losses in production and income.

\subsection{Empirical Review}

Absence of food security is food insecurity; food insecurity on the other hand represents lack of access to enough food and can either be chronic or temporary. Adeoti (1989) opine that chronic food insecurity arises from lack of resources to acquire and produce food thereby leading to persistent inadequate diet. FAO (2010) refers to food insecurity as the consequences of inadequate consumption of nutritious food bearing in mind that the physiological use of food is within the domain of nutrition and health. When individuals cannot provide enough food for their families, it leads to hunger and poor health. Poor health reduces one's ability to work and live a productive healthy life. Poor human development destabilizes a country's potential for economic development for generations to come (Otaha, 2013). According to FAO, et al. (2013), the core determinants of food security are availability, accessibility, utilization and stability.

The interplay of all these variables determines whether an individual, household, state or nation is food secured or not. This is because sustainable food security at the household level does not guarantee sustainable food security at the state or national level. The theoretical framework is based on Malthus theory on population, Thomas Malthus in his writing in the 18th century warned that global population would exceed the earth's capacity to grow food. Malthus suggested that population grows in geometrical progression while food production grows in arithmetical progression. Despite having been largely debunked, this theory has remained prominent in the discourse regarding hunger, the world's population carrying capacity and the need for increased agricultural technology. Malthus argument was a warning about population increase especially among the poor because he described the poor as breeding too rapidly and depriving the rest of the population of food; famine was seen as a natural defense against overpopulation. In the Nigerian situation, current production of food is far below to be a problem in solving food security in Nigeria.

The concept of sustainable development is the result of the growing awareness of the global links between mounting environmental problems, socio-economic issues to do with poverty and inequality and concerns about a healthy future for humanity. It strongly links environmental and socio-economic issues. The first important use of the term was in 1980 in the World Conservation Strategy (IUCN et al, 1980). This process of bringing together environmental and socio-economic questions was most famously expressed in the Brundtland Report's definition of sustainable development as meeting "the needs of the present without compromising the ability of future generations to meet their needs" (WCED, 1987, p43). This defines needs from a human standpoint; as Lee (2000, p32) has argued "sustainable development is an unashamedly anthropocentric concept".

Brundtland's definition and the ideas expressed in the report Our Common Future, recognise the dependency of humans on the environment to meet needs and well-being in a much wider sense than merely exploiting resources, "ecology and economy are becoming ever more interwoven - locally, regionally, nationally and globally" (WCED, 1987, p5). Rather than domination over nature our lives, activities and society are nested within the environment (Giddings et al, 2002). The report stresses that humanity, whether in an industrialised or a rural subsistence society, depends for security and basic existence on the environment, the economy and our well-being now and in the future need the 
environment. It also points to the planet wide interconnections, environmental problems are not local but global, so that actions and impacts have to be considered internationally to avoid displacing problems from one area to another by actions such as releasing pollution that crosses boundaries, moving polluting industries to another location or using up more than an equitable share of the earth's resources (by an ecological footprint (Wackernagel \& Rees, 1996) far in excess of the area inhabited).

Another area of debate is between the views of weak and strong sustainability (Haughton \& Hunter, 1994). Weak sustainability sees natural and manufactured capital as interchangeable with technology able to fill human produced gaps in the natural world (Daly \& Cobb, 1989) such as a lack of resources or damage to the environment. Solow put the case most strongly stating that by substituting other factors for natural resources "the world can, in effect, get along without natural resources, so exhaustion is just an event, not a catastrophe" (1974, p11).

Strong sustainability criticises this, pointing out that human-made capital cannot replace a multitude of processes vital to human existence such as the ozone layer, photosynthesis or the water cycle (Rees, 1998; Roseland, 1998). Deep Greens would go further in arguing that non-human species, natural systems and biodiversity have rights and values in themselves (Naess, 1989). The debate between strong and weak sustainability is, however, conducted mainly around environmental issues rather than taking account of socio-economic consequences.

Haughton (1999) has usefully summarised the ideas of sustainable development in five principles based on equity: futurity - inter generational equity; social justice - intra generational equity; transfrontier responsibility - geographical equity; procedural equity - people treated openly and fairly; inter-species equity - importance of biodiversity. These principles help give clarity to the ideas of sustainable development, link human equity to the environment, challenge the more bland and meaningless interpretations and provide a useful basis for evaluation of the different trends of sustainable development.

Beyond high prices of staple food items in Nigeria, drought and political situation in neightbouring countries like Chad, Cameroun and Niger seem to pose a threat to a state like Borno as they rely on the state for their food supplies. Another problem according to the Ministry of Agriculture and Water Resources, responsible for the food crisis in Nigeria is not unconnected with the fact that "Nigeria's agriculture is mainly rain-fed and she has not taken full advantage of its irrigation potential estimated between two and 2.5 million hectares". The area under irrigation is officially estimated at about 220,000 hectares or less than one per cent of the total areas under crops. The contribution of irrigated agriculture to crop production is, therefore, very small (May 5, 2008).

\subsection{Approaches to Food Security and Sustainability}

Perspectives on achieving food system sustainability i.e the three approaches are defined as follows: efficiency oriented; demand restraint perspective; and food system transformation.

\subsubsection{Efficiency}

This is perhaps the dominant approach. Its advocates include governments and food industry actors such as agricultural input businesses, farming unions, manufacturers and retailers. In essence this perspective is based on the assumption that the food security problem is a supply side challenge. More food needs to be produced to meet increasing and changing demand by growing populations; technological innovations and managerial improvements will enable us meet this demand in ways that impact less harmfully upon the environment while also enhancing nutrition (Adas et al., 2011).

\subsubsection{Demand Restraint}

For the efficiency mindset, the onus is on producers to develop appropriate techniques and strategies to reduce emissions; for the demand restraint perspective however, the problem lies with the consumer and 
with the companies who promote unsustainable consumption patterns. The end point in the supply chain e the consumer e becomes the focus of concern. Central to this perspective lies the conviction that excessive consumption is a leading cause of the environmental crisis we face. Its vision of change is therefore an overtly moral one: it explicitly criticises the status quo rather than e for reasons that may also be morally motivated but less explicit endorsing it.

The priority is to curb consumption of high impact foods. While in the 1990s the focus was particularly on foods high in 'food miles', as the findings of LCA research filtered through to the environmental community, combined with accusations of being 'anti poor' from poverty organisations, (MacGregor and Vorley, 2006), the locus of concern then shifted to animal products. The FAO's seminal Long Shadow report (FAO, 2006) and numerous LCA-inspired scientific and NGO publications have highlighted the heavy burden that livestock place on land, water, biodiversity e and their contribution to GHG emissions (Pelletier and Tyedmers, 2010; EC, 2006; Weber and Matthews, 2008; Stehfest et al., 2009; McAlpine et al., 2009).

Thus, while the efficiency perspective uses LCA to identify opportunities where technology and management can improve production efficiency to reduce the relative 'footprint' of existing consumption patterns, the demand restraint approach targets the consumption habits that ultimately drive production (they may also argue that the producers are seeking to generate the demand in the first place). This perspective also focuses on investigating alternatives to the status quo, should consumption patterns change.

Thus it draws not only upon attributional 'snapshot' LCAs that identify the most GHG intensive foods but also on those that adopt a 'what if?' approach to considering alternative scenarios. Increasingly, there is a focus on the opportunity cost and missed carbon sequestration potential arising from livestock production e it is argued that, if this land were not used for livestock it could regenerate naturally, or be used for other carbon sequestering purposes (Audsley et al., 2009; Schmidinger and Stehfest, 2012). In other words, while the efficiency perspective looks at the implications for land use of different production systems (extensive versus intensive) the demand restraint perspective complements this by considering different consumption patterns.

\subsection{Challenges of Sustainable Food Security In Nigeria}

Poverty is the major problem of food accessibility, availability and utilization. Poverty leads to insufficient income needed to meet household basic need. There are also other political and socioeconomic problems leading to food insecurity and these are discussed below:

\subsubsection{Government Policy}

Nigeria depended so much on agricultural productivity for its revenue until the exploration of oil in 1970s. The oil boom led to the negligence of the non-oil sectors especially the agricultural sector which used to be the major source of revenue for the country. The attention given to agriculture reduced drastically, farming reduced drastically, farmers needs were not attended to and the worst of all was that research and development in the sector slowed down causing a stagnation in food production.

Government policies with regard to agricultural production were rapid with plans hastily put together and little or no participation from those who are engaged in agricultural productivity. Moreover, policy change that championed increased incentive for local farmers for improved local food productions were neglected. Urban and community farming and even home gardening were no longer encouraged as land agents made it too difficult for people to obtain land for building as well as for agricultural productivity.

\subsubsection{Agricultural Practices}

The type of farming system prevalent in Nigeria is the traditional subsistent farming. This system is characterized by use of simple farm tools, small farm holdings, restricted access to credit facilities and low agricultural inputs, inadequate storage facilities, insecure markets for post-harvest products and 
exploitation of farmers by the middlemen. In terms of technology, Nigeria is still lagging behind when compared to other nations in Europe and Asia. Due to poverty and illiteracy, farmers do not have access to modern communication system with which they can access information regarding new technologies. Also there are few extension officers to transfer new technology to the farmers. Funding for agricultural research is still low in Nigeria. Also heavy importation of food crops affects productivity of local farmers because the small farmers cannot compete with the imported crops.

\subsubsection{Population Increase}

The demand for food exceeds the supply of food because the rate of growth of population is higher than the growth in agricultural productivity. Also the large population continues to relocate to the urban areas in search of white collar jobs which do not exist. This youth rural-urban drift makes it difficult for the country to be food secured.

\subsubsection{Environmental Issues}

Flood, drought, desertification are environmental issues affecting availability of food in Nigeria. Climate change affects food supply through loss of farmland, fluctuating food prices, increases in food borne illnesses and other food utilization issues (GCF, 2016). The recent environmental degradation through deforestation and flooding has wide negative implication for food production. For instance, in 2012 the country witnessed an unprecedented rainfall as a result of extreme weather. The rainfall resulted in severe flooding causing loss of agricultural crops, live stocks and human lives. According to Metu, Kalu and Ezenekwe (2015), the estimated loss of the country's GDP was worth N2.6 trillion. In the same period, share of agriculture value added to total GDP declined from $23.89 \%$ in 2010 to $22.05 \%$ in 2012 (WDI, 2014). Other environmental factors that may affect food security includes soil degradation, soil pollution and deforestation. Also air and water pollution from industrialization threaten both human and natural resources to an extent that food securities capabilities are damaged.

\subsubsection{Corruption}

Corruption in Nigeria has been on the increase leading to money budgeted for public utilities being siphoned for private use. This leads to decay in infrastructure especially rural infrastructure where majority of the farmers live and operate from. For instance, we have seen situations where money meant for importation of fertilizers are siphoned.

\subsection{Achieving Sustainable Food Security in Nigeria}

It should be noted that food production is only a means to an end. Solution to achieving sustainable food security must include reduction in the level of poverty because income must be improved to enable people meet the basic necessities of life, including food. However, reduction in poverty level takes a long time to be achieved; therefore, immediate solvable solutions must be taken and they include the following:

\subsubsection{Improved Agricultural Productivity}

Different projects/schemes have been established by different governments in the country in order to improve agricultural productivity, but they have failed because poor policy implementation. Agricultural productivity can be improved through encouragement of research. Research Institutes should be funded so as to encourage innovation and participatory research. Through research, foreign technology can be modified and applied in Nigeria. Inorganic fertilizers and chemicals can be replaced with alternatives such as cow waste and composite manure which are environmentally friendly.

Also extensions services should be encouraged and strengthened because through the extension services new technology can be transferred to the farmers. There should be storage facilities to enable farmers store their post-harvest crops. Farm products are perishables; farmers are forced to sell their products so quickly thereby making revenues that do not meet their daily need. The storage facilities can help them preserve their products before taking them to the market for sale. The storage facility will also help provide enough food reserve for the country. 


\subsubsection{Agricultural Biodiversity}

Improved agricultural biodiversity through improved agricultural practices will also increase food supply. Large scale farming involves planting one type of crop on a large piece of land, but with improved farming different genetically improved crop types and species may be planted on a piece of land. Monocropping also exposes crops to both pests and diseases and also increases the use of organic fertilizers and pesticides that erode soil biodiversity. In other to achieve sustainable food security, Nigeria farmers as well as government should embrace this modern food production technique that comes in form of agricultural biodiversity aimed at increasing livestock and crop production.

3. Environmental Management: Efforts to increase productivity have led to pressure on natural resources as well as environmental damage. There should be effective management of the environment by reducing the rate of deforestation. Trees should be planted as often as possible especially in the desert. Providing habitat for agricultural pests and increasing resilience to shocks and long-term climate change can help in the improvement and management of natural resources. Tree planting should be encouraged because forest trees outside the forest helps in protecting soil and water resources, promotes soil fertility and provides protection from extreme weather events.

\subsubsection{Policy Changes}

Sustainable food security can be achieved if the government adopts inclusive growth in its development efforts. Development should be participatory and environmentally friendly. People-Centered agricultural development puts the farmers first and attacks poverty with opportunities and education. It requires involving the rural people in decision making stages of agriculture productivity. The inability of government to involve these sets of people in defining and designing projects has led to the failure of some of these projects. There should be well designed social protection systems -such as risk insurance scheme and community empowerment- to help households sustain their resilience to shocks.

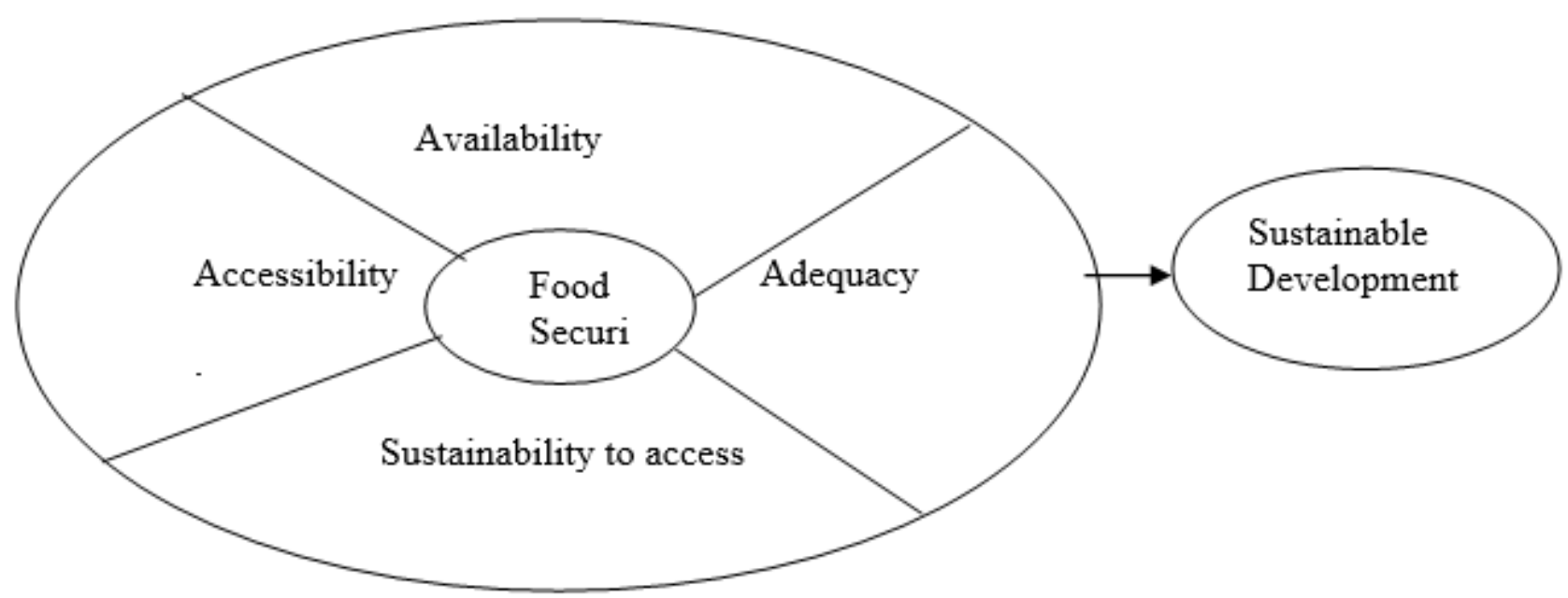

Source: Developed by the researchers, 2019.

\section{Research Methodology}

This study is intended primarily to examine the impact of applying the smart goals approach (four cardinal components) in assessing the level of success on food security initiatives on sustainable development in North Eastern Nigeria. To achieve this aim, the study will employ survey research method. Survey research is a research design in which data are collected straight from the field within a particular period of time. Therefore, this method is suitable when a phenomenon or behavior of entities needed to be observed in time. This study will cover the period from March, 2019 to May, 2019. 
The researchers developed a model for the study on the four elements of food security on sustainable development to clearly show the relationship between the independent variables and the dependent variable. This study examined the impact of food security and sustainable development in North Eastern Nigeria. Hence, the entire six (6) States in the North East form the population of the study with 498 respondents among government agencies, corporate bodies, Non-governmental organizations, buyers and sellers within each state in the zone was the targeted population of the study.

This study used both proportional stratified sampling and purposive random sampling techniques. First, proportional stratified sampling technique was applied to determine the number of government agencies, corporate bodies, Non-governmental organizations, buyers and sellers within each state in the North East Zone of Nigeria so as to have fair representation.

\section{Research Instrument}

The study was field survey in nature as such questionnaires were used for data gathering. The questionnaire was designed in sections with different items on Food security, sustainable development of which its reliability and validity can be tested. The questionnaire was designed to meet the needs of the study. The questionnaire was structured using the five-point Likert scale for accuracy. The study also include the demographic section for the respondents.

\section{Data Analysis}

The primary data collected from the respondents were analyzed using statistical package. The statistical software SPSS v.20 was used in the data analysis. The statistical tools that was used in carrying out the analysis are as correlation analysis and regression Analysis.

\section{Result and Discussion}

\subsection{Descriptive Statistic}

Table 1 Shows the characteristic and contents of research items for the study. Findings shows that Food Availability has an average of 4.12 and standard deviation of 0.849 while 1.00 and 5.00 are the minimum and maximum respectively. The standard deviation shows that the data of Food Availability are far spread across the mean of the data; by implication the Food Availability of states to state within the North eastern Nigeria are not the same. This is further confirmed by the differences between the maximum and minimum.

Food Adequacy has an average of 3.15 and standard deviation of 0.828 , Food Accessibility has a mean score of 3.02 and a standard deviation of 0.854 Equally, Food security has a mean score of 3.22 and a standard deviation of 0.841 , finally, Sustainability has a mean score of 4.24 and a standard deviation of 0.781

In conclusion, the result on the data reveals that there are great deals among the component of food security in terms of food availability, food adequacy, food accessibility, food security and sustainability within North Eastern Nigeria. 
Table 1: Descriptive Statistics $(\mathrm{N}=498)$

\begin{tabular}{|l|l|l|l|l|}
\hline Variable & Mean & Std Dev. & Min & Max \\
\hline $\begin{array}{l}\text { Food } \\
\text { Availability }\end{array}$ & 4.12 & 0.849 & 1.00 & 5.00 \\
\hline $\begin{array}{l}\text { Food } \\
\text { Adequacy }\end{array}$ & 3.15 & 0.828 & 1.00 & 5.00 \\
\hline $\begin{array}{l}\text { Food } \\
\text { Accessibility }\end{array}$ & 3.02 & 0.854 & 1.00 & 5.00 \\
\hline Food security & 3.22 & 0.841 & 1.00 & 5.00 \\
\hline Sustainability & 4.24 & 0.781 & 1.00 & 5.00 \\
\hline & & & & \\
\hline
\end{tabular}

Source: Extracted from SPSS (version 20.), 2019

\subsection{Correlation Analysis}

The correlation matrix seeks to determine the relationships that exist between variables used in the research. Table 2 indicates the relationship that exists between Food security intiatives components on sustainable development. The relationship between food Availability and Food Adequacy is positive at 0.122, this means that an increase in food Availability lead to $12.2 \%$ increase in Food Adequacy and vice versa. This is actually obvious that society with high food availability is expected to have a high Food Adequacy for its members. Also, Food Availability is positive but insignificantly correlated to Food accessibility, food security and sustainability with a coefficient of $0.049,0.099$ and 0.117 respectively. This implies that a small increase in food Availability leads to an insignificant increase in Food accessibility, food security and sustainability.

Food Adequacy has positive relationship with food accessibility, food security and sustainability loyalty and Bank Profitability with $0.181^{* *}, 0.469^{* *}$ and 0.030 , respectively. This indicates that an increase in food adequacy leads to increase in food accessibility, sustainability and a high increase in food security of $46.9 \%$

Table 2: Correlation Analysis

\begin{tabular}{|l|l|l|l|l|l|}
\hline Variables & $\begin{array}{l}\text { Food } \\
\text { Availability }\end{array}$ & $\begin{array}{l}\text { Food } \\
\text { Adequacy }\end{array}$ & $\begin{array}{l}\text { Food } \\
\text { Accessibil } \\
\text { ity }\end{array}$ & $\begin{array}{l}\text { Food } \\
\text { security }\end{array}$ & Sustainability \\
\hline $\begin{array}{l}\text { Food } \\
\text { Availability }\end{array}$ & 1.000 & & & & \\
\hline Food Adequacy & 0.122 & 1.000 & & & \\
\hline $\begin{array}{l}\text { Food } \\
\text { Accessibility }\end{array}$ & 0.049 & $0.181^{* *}$ & 1.000 & & \\
\hline Food security & 0.099 & $0.469^{* *}$ & $0.207^{* *}$ & 1.000 & \\
\hline Sustainability & $0.117^{* *}$ & 0.030 & 0.079 & 0.064 & 1.000 \\
\hline
\end{tabular}

Source: Extracted from SPSS (version 20.), 2019

\subsection{Regression Analysis}

The regression Analysis as present in the model summary reveals that food security components (food availability, food adequacy, food accessibility and food security) on sustainability development has $\mathrm{R}$ square of 0.018 and adjusted $\mathrm{R}$ square of -0.050 . The result shows that food sustainability initiative has negative and insignificant effect on sustainable development within the North Eastern Part of Nigeria. The 
Durbin-Watson equally shows a value of 2.165. Based on the rule of thumb as give by Hair, Black and Brown, (2010) that it ranges between 1.5 and 2.5. From the result the value falls between 1.5 to 2.5 therefore the is presence of autocorrelation. The means that the various were used in the past and can be use in the present study to measure sustainable development in Nigeria.

Food security initiative has $-5.0 \%$ effects on sustainable development among the state in North eastern part of Nigeria. By implication food security initiation does not exert any impact on sustainable development in North eastern Nigeria. This could account for the current and persistence activities of the insurgents in the region which resulted to destructions of property and asset of human living within the region. All government programs to ensure food for all end up in vain as the activities of the insurgent and mismanagement also attributed to the negative effect of food security initiative and sustainable development.

There are a lot of factors that contributed to the negative result from the study, these include

- A severe drought reduce a harvest or kill livestock

- War or conflict prevents food import to certain region

- Availability of food was determined by price affordability.

- Poor instrument of government policy to ensure food security

- Due to natural calamity total production of food grains decreases, thereby affecting the adequacy of food for all

- The broken bridge due to insurgent attach can hamper access to food or trade market

Table 3: Regression Analysis (Model Summary)

\begin{tabular}{|l|l|l|l|l|l|}
\hline Model & $\mathrm{R}$ & R Square. & $\begin{array}{l}\text { Adjusted R } \\
\text { Square }\end{array}$ & Sig. F Change & $\begin{array}{l}\text { Durbin- } \\
\text { Watson }\end{array}$ \\
\hline 1 & $0.135^{\mathrm{a}}$ & .018 & -.050 & .897 & 2.165 \\
\hline & & & & & \\
\hline
\end{tabular}

a. Predictors: (Constant), Food security, Food Availability, Food Accessibility, Food Adequacy

b. Dependent Variable: Sustainability

Source: Extracted from SPSS (version 20.), 2019

\section{Conclusion and Recommendation}

From the study it is likely to say that the determinants of food security were actually captured and they all proved to be determinants because they all had effects on food prices relative to food security initiatives. It is observed that the food security initiative does not contribute immensely to the sustainable development in the north eastern part of Nigeria compared to other region in ht country. From the findings of this research, food security initiative does not have effect on sustainability due to high price of food in the country resulted from high cost of production prevailing in the agricultural sector, brought about by excessive importation of agricultural inputs, lack of adequate use of improved technology, inadequate subsidies, grants, etc. Moreover, the increase in prices of food as a result of increase in agricultural gross domestic product is also due to the fact that the available food is not sufficient for the large population in the country. The rising population poses a hindrance to the supply of food because the supply falls short of the food demand, bringing about food price inflation. In a nut shell, the prevailing high cost of production in the country and the ever increasing population brings about a negative impact on food security and sustainable development in Nigeria. Large volume of importation of food into the country where foreign exchange is not sufficient and exchange rate prevailing in the country is high, or where foreign exchange is needed for the importation of other essential resources actually imposes a negative impact on food security, thereby causing a detrimental effect on sustainable development in North 
Eastern part of Nigeria. The positive effect food imports have on prices of food is as a result of the low import capacity of our country, which depends greatly on our export earnings, debt service obligations, and foreign exchange reserve. It is observed that through food security initiative and other policies adopted by the government should have positive impact on sustainable development but due to mismanagement of these policies in the country, the positive effect of the programmes in the country later turn out to be negative and insignificant due to the collapse of the policies and this causes a negative effect on food security initiative in the country. Food security initiative in Nigeria can be improved if all the measures discussed and recommended in the study are carried out. However, Nigeria is a very rich and blessed country that is capable of attaining economic development in terms of food security if certain hindrances like corruption can be expelled in the country. Also the factors that determine food security were actually revealed to have negative influences on food security in the period examined. Hence, it is to be concluded that for a sustained food security to be achieved in this country, there has to be a stability in food prices rather than inflation which causes food insecurity. Moreover, increased productivity should be directed towards keeping pace with the growing population and through improvement in technology, there would be sufficient food available in the country for both consumption and export which would yield high foreign exchange in order to increase growth in the economy trailing a path for development.

\section{References}

Abdullahi, A-Food security in Nigeria: How close are we?| 2008, pp 4-6 [A paper presented at the Federal Radio Corporation's Annual Lecture- Abuja].

Adeoti, J -Economic crises in developing countries: The food dimension\| Ilorin Journal of

Business and Social Sciences, 1989.

Adeyeye V.A (1992): “An assessment of food security in Nigeria”. Final report of a study commissioned by FAO, Rome.

Dogondaji, M.S (2013) - Towards mitigating the impacts of climate change on food security: A global perspectivell. Academic Journal of Interdisciplinary Studies,

E. N. Egbuna, E.N (2001) -Food security in Nigeria: The challenges and way forward\|, [Paper presented at the Annual conference of The Nigerian Economic Society. Theme: Natural Resource use, the Environment and Sustainable Development, pp 307- 325]

Ekpenyoung, S. Alfred, And R. Lasisi, (2016). Food importation and rural economy: The challenges for 186 3rd International Conference on African Development Issues (CU-ICADI) ISSN:2449-075X

F.A.O (2001). Perspective study on Agriculture Development in the Shellian Countries Vol. 3 F. A.O. (2010). World Food Crisis the price of Neglect

Gurkan A.A, (1995): “The mathematics of hunger". CERES 27(2): 31-33.

Honfoga B.G and J. G. M. Van Den Boon, (2001). Food consumption patterns in Central West Africa, 1961 to 2000, and challenges to combating malnutrition, Food and Nutrition Bulletin, vol. 24(2), pp.167-182.

Idachaba, F. S. (2006). Strategic and Policies for Food Security and Economic Development in Nigeria. Lagos: CBN.

Idiku, F.O, A. O. Angba and M. E. Ushie, (2016). Food insecurity challenges and sustainable agricultural development in Nigeria,\| n.d [Retrieved from http://www.ssrn.com/link/OIDA-int-Journal Sustainable-Dev.html Accessed 09/03/16].

Kainth, G.S (2010). Food security and sustainability in India, [Retrieved from http://www.merinews.com/article/. Accessed 12/10/2011].

Nigeria Demographic and Health Survey, (2013). Retrieved from http://www.microdata.worldbank.org Accessed 12/03/2016].

Makinde K.O (2000): "Measurements and determination of food security in Northern Guinea Savannah of Nigeria". Unpublished PhD Thesis, Department Agricultural Economics, University of Ibadan.

Metu, A; U. C. Kalu and R.U. Ezenekwe, (2015). Demographic pattern and sustainable development in Nigeriall. In A. C. Mbanefo and Au. N. Nnonyelu, Eds. Challenges of sustainable development: A social sciences approach. Awka, Fab Anieh Nig. Ltd, pp. 129 - 140.

Olayemi J.K (1996):“Food security in Nigeria; Development policy center Policy Report 2, Ibadan. 
Ojo, E.O and F. P. Adebayo, F. P. (2012). Food security in Nigeria: An overview, European Journal of Sustainable Development, vol. 1(2), pp. 199-222.

Olawepo, R.A (2012). Food security and challenges of urban agriculture in the third world countries, Food Production Challenges Task

Oseni A.T (2001): Demand analysis of some selected food item in Surulere local government area of Lagos state: Implication on food security. Unpublished B.sc project department of Agricultural Economics University of Ibadan, Ibadan, Nigeria.

Siamwalla A,and Valdes A (1994): Food security in developing countries; international issues. IFPRI Washington D C.

World Bank (1986): Poverty and Hunger; Issues and option for food security in developing countries. A World Bank policy study, Washington. 
